Proc. Indian Acad. Sci. (Earth Planet. Sci.), Vol. 99, No. 1, March 1990, pp. 99-117.

(C) Printed in India.

\title{
Application of infrared spectroscopy to studies of silicate glass structure: Examples from the melilite glasses and the systems $\mathrm{Na}_{2} \mathrm{O}-\mathrm{SiO}_{2}$ and $\mathrm{Na}_{2} \mathrm{O}-\mathrm{Al}_{2} \mathrm{O}_{3}-\mathrm{SiO}_{2}$
}

\author{
W R TAYLOR* \\ Geology Department, University of Tasmania, GPO Box 252C, Hobart, Australia 7001 \\ *Present address: Department of Geology, University of Western Australia, Nediands, \\ Western Australia 6009
}

\begin{abstract}
Infrared (IR) and Raman spectroscopic methods are important complementary techniques in structural studies of aluminosilicate glasses. Both techniques are sensitive to small-scale $(<15 \AA)$ structural features that amount to units of several $\mathrm{SiO}_{4}$ tetrahedra. Application of IR spectroscopy has, however, been limited by the more complex nature of the IR spectrum compared with the Raman spectrum, particularly at higher frequencies $\left(1200-800 \mathrm{~cm}^{-1}\right)$ where strong antisymmetric $\mathrm{Si}-\mathrm{O}$ and $\mathrm{Si}-\mathrm{O}-\mathrm{Si}$ absorptions predominate in the former. At lower frequencies, IR spectra contain bands that have substantial contributions from 'cage-like' motions of cations in their oxygen co-ordination polyhedra. In aluminosilicates these bands can provide information on the structural environment of Al that is not obtainable directly from Raman studies. A middle frequency envelope centred near $700 \mathrm{~cm}^{-1}$ is indicative of network-substituted $\mathrm{AlO}_{4}$ polyhedra in glasses with $\mathrm{Al} /(\mathrm{Al}+\mathrm{Si})>0.25$ and a band at $520-620 \mathrm{~cm}^{-1}$ is shown to be associated with $\mathrm{AlO}_{6}$ polyhedra in both crystals and glasses. The IR spectra of melilite and melilite-analogue glasses and crystals show various degrees of band localization that correlate with the extent of $\mathrm{Al}, \mathrm{Si}$ tetrahedral site ordering. An important conclusion is that differences in $\mathrm{Al}$, Si ordering may lead to very different vibrational spectra in crystals and glasses of otherwise gross chemical similarity.
\end{abstract}

Keywords. Infrared spectroscopy; silicate; aluminium co-ordination; aluminosilicate glasses; melilite; melilite-analogue glasses; akermanite; gehlenite; sodamelilite.

\section{Introduction}

In disordered silicate glasses there is no long-range structural periodicity. Methods of structural analysis that are applicable to crystalline solids e.g. conventional X-ray diffraction techniques, require the existence of order on a scale of hundreds of atomic spacings but in glasses no such order exists, and other techniques must be used as structural probes.

Models for the structure of silica and silica-metal oxide glasses range over two extremes. The random network hypothesis, originally proposed by Zachariasen (1932), has no provision for the presence of short range order or crystal-like features. In silica glass, the model assumes an arrangement of inter-connected $\left[\mathrm{SiO}_{4}\right]$ tetrahedra completely lacking periodicity due to a random distribution of $\mathrm{Si}-\mathrm{O}-\mathrm{Si}$ bond angles. At the other extreme lies the crystallite theory (Randall et al 1930; illustrated by Wright and Leadbetter 1976) that proposes a glass structure based on highly ordered microcrystalline regions with dimensions of several tens of angstroms that strongly resemble the structure of the corresponding equilibrium solid. Much evidence exists to suggest that the real structure of silicate glasses lies between these two models, which really only represent extremes in the degree of the short range order present. 
Bottinga et al (1981) have shown that the dimensions of short range structures are probably quite small and amount to several $\left[\mathrm{SiO}_{4}\right]$ tetrahedra only $(\sim 5-15 \AA)$. The theory of vibrational spectroscopy as applied to silicate glasses (Brawer 1975; Brawer and White 1974) shows that infrared (IR) and Raman spectroscopy are sensitive to such small-scale structural features. For this reason, vibrational spectroscopic techniques have become very popular tools in experimental geochemistry over the last ten years' (see review by McMillan and Piriou 1983) although they have their limitations. In this respect the extent to which vibrational spectroscopy can provide insights into the full bonding topology of silicate glasses has not yet been fully assessed.

The small-scale sensitivity, particularly at higher frequencies, of IR and Raman spectra, implies that information on the overall structure i.e. the interconnection between smaller structural units may not be readily obtainable (McMillan 1984a). However, this small-scale sensitivity can be used to advantage in studies on the solubility mechanisms of small molecules such as $\mathrm{H}_{2} \mathrm{O}$ and $\mathrm{CO}_{2}$ in silicate glasses. Molecular dynamic and Monte Carlo simulations (Woodcock et al 1976; Borgianni and Granati 1979; Matsui and Kawamura 1984) have shown some promise in providing an overall picture of silicate melts and glasses, emphasizing the need to employ a wide range of techniques in any structural study.

In the geological literature much effort has been placed on correlating structural information on silicate melts and glasses with observed physical properties such as viscosity-pressure relationships and diffusion coefficients (e.g. Mysen et al 1980, 1982). Considerable attention has also been devoted to understanding the effects of minor and volatile component additions to silicate liquids. It is well known that such components have an effect on natural and synthetic systems that is large in relation to their level of abundance (e.g. Kushiro 1975). The mechanisms of $\mathrm{TiO}_{2}, \mathrm{P}_{2} \mathrm{O}_{5}$ and oxidized volatile $\left(\mathrm{H}_{2} \mathrm{O}, \mathrm{CO}_{2}\right)$ dissolution have been investigated by Raman spectroscopy and the results have been summarized by Mysen et al (1982). More recent work on the $\mathrm{H}_{2} \mathrm{O}$ solubility mechanism by Stolper $(1982 \mathrm{a}, 1982 \mathrm{~b})$ and McMillan et al (1983) using IR spectroscopic techniques have found, contrary to the Raman investigations, that a substantial fraction of the dissolved water is present in molecular form. This highlights the importance of the complementary nature of Raman and IR techniques since use of one technique by itself may provide only part of the answer sought. The differing activity of Raman and IR vibrational modes makes the former technique more powerful in investigations of the silicate glass network structure but indirect and often ambiguous in studies of volatile solubility (e.g. Mysen et al 1980) and cation co-ordination environments (e.g. Sharma and Simons 1981; McMillan et al 1982).

In this paper the aim is to emphasize the range of structural information obtainable by IR spectroscopy mindful of the much larger data-base provided by Raman spectroscopic studies of silicate glasses. A comparison of the major IR and Raman absorption bands and their inferred structural assignment is pesented in the next section, and examples of IR applications from the systems $\mathrm{Na}_{2} \mathrm{O}-\mathrm{SiO}_{2}, \mathrm{Na}_{2} \mathrm{O}-\mathrm{Al}_{2} \mathrm{O}_{3}-$ $\mathrm{SiO}_{2}$ and from melilite glasses (akermanite, gehlenite, sodamelilite) are presented in following sections. 


\section{Background}

The structure of disordered solids cannot be expressed explicitly in terms of nearest neighbour co-ordination numbers, bond lengths and bond angles as is the case with crystalline solids. Instead, one is faced with a statistical distribution about some mean structure pointing to the existence in melts and glasses of a range of easily accessible configurations separated by only small energy barriers. For example in vitreous silica a variety of techniques have shown that there is a broad distribution of $\mathrm{Si}-\mathrm{O}-\mathrm{Si}$ bond angles from $170-130^{\circ}$ with the most probable angles in the range $155-140^{\circ}$ (Greaves et al 1981; Dupree and Pettifer 1984). This variability leads to vibrational spectra that have broad, often poorly resolved, band envelopes with bandwidths of a half-height as much as $50-300 \mathrm{~cm}^{-1}$, ten times more than the width of comparable crystalline compounds. The elucidation of structural information, therefore, frequently requires the use of special procedures such as spectral deconvolution and spectral subtraction. The question of whether these techniques can provide unique structural solutions is the subject of debate in the literature (McMillan et al 1982; McMillan and Piriou 1983). However it is clear that absorption bands must be assigned with reference to all available experimental and theoretical information. For Raman spectra, the arguments leading to band assignments have been discussed by McMillan (1984a). No detailed summary is as yet available for IR spectra although many bands are both IR- and Raman-active (though with differing intensities) and assignments will in many cases be applicable to both spectra.

In simple system silicate and aluminosilicate glasses, both IR and Raman spectra have prominent band envelopes (variably resolved into separate bands) in the high-frequency $\left(1200-800 \mathrm{~cm}^{-1}\right)$, middle-frequency $\left(800-650 \mathrm{~cm}^{-1}\right)$ and low frequency $\left(650-400 \mathrm{~cm}^{-1}\right)$ regions. A brief description of their structural assignment is given below:

\subsection{High-frequency band envelope}

In the Raman spectra of silicate glasses the high frequency envelope is composed of polarized bands due to symmetric $\mathrm{Si}-\mathrm{O}$ stretching motions of silicate units containing [SiO $\left.{ }_{4}\right]$ tetrahedra with: one $\left(\sim 1100-1050 \mathrm{~cm}^{-1}\right)$, two $\left(\sim 1000-950 \mathrm{~cm}^{-1}\right)$, three $\left(\sim 900 \mathrm{~cm}^{-1}\right)$ and four $\left(\sim 850 \mathrm{~cm}^{-1}\right)$ non-bridging oxygens (NBO). In the notation of Engelhardt et al (1975) these are designated $Q_{3}, Q_{2}, Q_{1}$ and $Q_{0}$ respectively. Mysen et al (1980) and Virgo et al (1980) ascribe these bands to the presence of a number of discrete anionic structural units i.e. 3-d networks, sheets, infinite chains, dimers and monomers with $\mathrm{NBO} / \mathrm{Si}$ ratios of $0,1,2,3$ and 4 respectively. This interpretation has been questioned by McMillan (1984a, b) who presents strong evidence for the major high frequency bands being highly localized in character and as such, unable to provide any information on the linkage of adjacent tetrahedral groups. For example, McMillan (1984a) and McMillan and Piriou (1983) find that discrimination between infinite chains, $\left[\mathrm{Si}_{2} \mathrm{O}_{6}\right]_{\infty}$, and ring structures of equivalent $\mathrm{NBO} / \mathrm{Si}$ ratio is not possible based solely on high frequency Raman bands. Thus an interpretation of the Raman bands in terms of Engelhardt et al's Q-species, where there is no inherent assumption about the presence or absence of longer-range $(>10 \AA)$ structures, may be most appropriate. 
Unlike the relatively simple Raman high frequency envelope, the infrared spectrum in this region includes, in addition to symmetric $\mathrm{Si}-\mathrm{O}$ stretching bands, a series of bands arising from antisymmetric stretches of non-bridging and bridging $\mathrm{Si}-\mathrm{O}$ bonds; designated $v_{\text {as }}\left[\mathrm{Si}-\mathrm{O}^{-}\right]$and $v_{\text {as }}[\mathrm{Si}-\mathrm{O}-\mathrm{Si}]$ respectively.

In heteropolar solids, an absorption will be infrared-active when dissimilar atoms vibrate out-of-phase and Raman-active when they vibrate in-phase (Laughlin and Joannopoulos 1977). For example, strong negative correlations between silicon and oxygen displacements at $1080 \mathrm{~cm}^{-1}, 800 \mathrm{~cm}^{-1}$ and $450 \mathrm{~cm}^{-1}$ were found in the model of Laughlin and Joannopoulos (1977) for vitreous silica; all three values agree well with the observed IR activity.

Infrared spectra of silicate glasses in the high-frequency region tend to be much more complex than their Raman counterparts. In simple binary metal oxide-silica systems of high $\mathrm{NBO} / \mathrm{Si}$ two distinct envelopes, corresponding to bridging and non-bridging $\mathrm{Si}-\mathrm{O}$ vibrations, may be resolved in this region (e.g. Ferraro and Manghnani 1972; see later). For the same silica content, band shape is strongly influenced by the nature of the metal oxide present (Sanders et al 1974) with ions of largest $\mathrm{z} / \mathrm{r}$ (e.g. $\mathrm{Mg}^{2+}$ ) least disrupting the structural units present in vitreous silica (de Jong et al 1981).

\subsection{Middle frequency envelope}

The mid-range envelope $\left(800-650 \mathrm{~cm}^{-1}\right)$ is of moderate strength in both temperaturecorrected Raman (Seifert et al 1982) and infrared spectra. It is composed of at least two and probably more band components (Seifert et al 1982). McMillan et al (1982) have suggested that the band near $800 \mathrm{~cm}^{-1}$ in silica glass is mainly associated with motions of $\mathrm{Si}$ atoms against their tetrahedral oxygen cage, with little displacement of associated oxygen. This is consistent with observed isotope shifts (Galeener and Mikkelsen 1981; Galeener and Geissberger 1983) and with molecular dynamics calculations (Angell et al 1982; Giarofalini 1982).

In the case of melts lacking a semi-rigid polymerized network (i.e. those with $\mathrm{NBO} / \mathrm{Si}>1$ ) McMillan (1984a) suggests that the mid-range vibrations might transform or couple to other modes having a greater degree of oxygen motion. This is evident in melts of $\mathrm{NBO} / \mathrm{Si}$ approaching 4 where the mid-range band becomes progressively weaker with decreasing $\mathrm{SiO}_{2}$ content; in vitreous fayalite, for example, the mid-range band is only present as a very weak shoulder (Kusabiraki and Shiraishi 1981).

Bell and Dean (1972) and Laughlin and Joannopoulos (1977) also describe the mid-range band as a vibration involving substantial $\mathrm{Si}$ motion but include an additional contribution from $\mathrm{Si}-\mathrm{O}-\mathrm{Si}$ "bridge bending" (i.e. in-plane oxygen motion bisecting the $\mathrm{Si}-\mathrm{O}-\mathrm{Si}$ bond angle). Ferraro and Manghnani (1972) fourd both strong pressure and compositional dependencies for the $800-700 \mathrm{~cm}^{-1}$ envelope in the system $\mathrm{Na}_{2} \mathrm{O}-\mathrm{SiO}_{2}$. The effect of pressure is to compress the inter-tetrahedral linkages effectively decreasing the volume of the $\left[\mathrm{SiO}_{4}\right]$ co-ordination polyhedra and thus raising the vibrational frequency. This behaviour together with the pronounced dependence of band position on NBO/Si led Ferraro and Manghnani (1977) to infer a strong degree of delocalization and hence a "pseudo-lattice-like" character for this band. 


\subsection{Low frequency envelope}

The low frequency region $\left(650-400 \mathrm{~cm}^{-1}\right)$ in Al-free silicate glasses includes a series of strong to moderate intensity unresolved bands that in the IR appear mostly below $550 \mathrm{~cm}^{-1}$ and in the Raman spectrum generally in the range $650-450 \mathrm{~cm}^{-1}$. In vitreous silica, the strong IR band near $470 \mathrm{~cm}^{-1}$ has been assigned largely to "rocking" motions of bridging oxygen where $\mathrm{O}$ vibrates in a direction perpendicular to the $\mathrm{Si}-\mathrm{O}-\mathrm{Si}$ plane (Laughlin and Joannopoulos 1977). A weak shoulder near $550 \mathrm{~cm}^{-1}$ in the IR is probably associated with vibrations of a predominantly "bending" character in which oxygen motion bisects the $\mathrm{Si}-\mathrm{O}-\mathrm{Si}$ bond angle. Two sharp bands at $604 \mathrm{~cm}^{-1}$ and $490 \mathrm{~cm}^{-1}$ in the Raman spectrum of vitreous silica have been attributed to localized modes associated with "broken bond" defects (Bates et al 1974). This assignment is, however, by no means certain and both absorption bands have been ascribed, on isotopic evidence, to the presence of 3- and 4-membered ring structures (Galeener and Geissberger 1983).

In the systems $\mathrm{M}_{2} \mathrm{O}-\mathrm{SiO}_{2}, \mathrm{MO}-\mathrm{SiO}_{2}$ and in the fully polymerized $\mathrm{MAlO}_{2}-\mathrm{SiO}_{2}$, $\mathrm{M}_{0.5} \mathrm{AlO}_{2}-\mathrm{SiO}_{2}$ aluminous systems, where $\mathrm{M}=$ monovalent or divalent alkali or alkaline earth cation, polarized bands of moderate to strong intensity appear in the Raman spectrum over the range $500-650 \mathrm{~cm}^{-1}$ (Seifert et al 1982; McMillan 1984a). These bands usually occur as an unresolved band envelope but in systems containing cations of low $z / r$, such as the $\mathrm{K}_{2} \mathrm{O}-\mathrm{SiO}_{2}$ series glasses investigated by Verweij and Konijendijk (1976), they may be partly resolved. These absorptions are weakly active or inactive in the IR. Hass (1970); Mysen et al (1980) and Seifert et al (1982) have suggested a correlation with the "defect" bands of silica glass, however, McMillan (1984a) ascribes the observed absorptions to new bands unable to be simply derived from those of vitreous silica. McMillan (1984a) infers a high degree of vibrational localization for the $500-600 \mathrm{~cm}^{-1}$ bands and correlates absorption frequency with the presence of units of differing $\mathrm{NBO} / \mathrm{Si}$.

The most useful description of bands in the low frequency region, judging by the analysis of Furukawa et al (1981), is as bending plus stretching (deformation) modes involving a high degree of oxygen displacement at $\mathrm{Si}-\mathrm{O}-\mathrm{Si}$ bridges. "Rocking" describes predominantly out-of-plane motions of oxygen and "bending" sensu stricto describes in-plane motions.

\subsection{Role of aluminium in aluminosilicate glasses}

Many recent publications in the geological literature have been devoted to the understanding of the structural role of aluminium in aluminosilicate melts and glasses. The ionic radius of aluminium is such that it is found in four-, five- and six-fold co-ordination to oxygen in aluminate and aluminosilicate minerals. This variability coupled with aluminium's known amphoteric behaviour, is good reason for presuming that $\mathrm{Al}^{3+}$ may adopt dual network-modifying and network-forming roles in the liquid or vitreous state. The usual interpretation (e.g. Mysen et al, 1982) is that when sufficient alkali or alkaline earth cations are present to charge compensate $\mathrm{Al}^{3+}$, as $\mathrm{NaAlO}_{2}$ or $\mathrm{Ca}_{0.5} \mathrm{AlO}_{2}$ complexes for example, then $\mathrm{Al}$ will be present in tetrahedral co-ordination. This idea is borne out by $\mathrm{X}$-ray, thermochemical and Raman 
spectroscopic studies of glasses in the system $\mathrm{NaAlSiO}_{4}-\mathrm{SiO}_{2}$ (Taylor and Brown 1979; Mysen et al 1980; Seifert et al 1982; Navrotsky et al 1982).

Interpretation of high frequency Raman spectrum of aluminosilicates is controversial. Mysen et al (1981) believe that the bands are a result of coupled ( $\mathrm{Si}, \mathrm{Al})-\mathrm{O}$ vibrations, but McMillan et al (1982) infer a dominant $\mathrm{Si}-\mathrm{O}$ character modified only slightly by the $\mathrm{Al}^{3+}$ cation. McMillan et al (1982) believe $\mathrm{Al}-\mathrm{O}$ stretching vibrations will occur at frequencies $20-30 \%$ less than $\mathrm{Si}-\mathrm{O}$ vibrations; the authors expect components of $\mathrm{Al}-\mathrm{O}$ stretching and $\mathrm{Al}$ "cage" motions to appear in the $700-900 \mathrm{~cm}^{-1}$ region with a weak Raman intensity but a strong to moderate IR activity. In the low frequency region associated dominantly with bridging oxygen motions, McMillan et al (1982) ascribe new bands at $\sim 590 \mathrm{~cm}^{-1}$ and $\sim 490 \mathrm{~cm}^{-1}$, occurring over a wide compositional range in system $\mathrm{Ca}_{0} \cdot \mathrm{AlO}_{2}-\mathrm{SiO}_{2}$ and $\mathrm{NaAlO}_{2}-\mathrm{SiO}_{2}$ glasses, to the presence of $\mathrm{Al}-\mathrm{O}-\mathrm{Al}$ and $\mathrm{Al}-\mathrm{O}-\mathrm{Si}$ linkages respectively. These results together with ${ }^{27} \mathrm{Al}$ solid state NMR work (de Jong et al 1983) suggest that the "aluminium avoidance principle", i.e. instability of aluminate condensates or clusters, is not a strict rule in aluminosilicate glasses (cf. Matsui and Kawamura 1984).

There has been considerable controversy in geological literature concerning pressure-induced Al co-ordination changes in silicate liquids (see Kushiro 1978, 1980, 1984; Velde and Kushiro 1978; Mysen et al 1982; Ohtani et al 1985). Part of this controversy concerns the suitability of Raman spectroscopy in detecting $\mathrm{AlO}_{4} \rightarrow \mathrm{AlO}_{6}$ co-ordination changes. Due to weak band intensities and possible coupling effects in the Al-O region of the Raman spectrum (Sharma and Simons 1981; Sharma et al 1983), Al co-ordination changes can only be inferred indirectly by detecting changes in NBO content.

Infrared spectroscopy has been suggested by Tarte $(1965,1967)$ as useful for directly characterizing $\mathrm{Al}-\mathrm{O}$ co-ordination polyhedra, provided the vibrating unit remains largely independent of other groups. This appears valid in the crystalline aluminosilicates and the few glasses investigated by Tarte (1967). Many cations in the glass phase, including $\mathrm{Al}$, can be identified from their characteristic $\mathrm{MO}_{n}(\mathrm{M}=$ metal cation, $n=$ co-ordination number) "cage" vibrations which appear to be quite localized in character (Rao and Elliott 1981). The vibration frequency depends on the mass of the cation, the size of the oxygen polyhedron (both bond length and co-ordination number) and the nature of the co-ordinating oxygen ions (effective charge and type of network attachment). For $\mathrm{Al}$, the approximation that these vibrations remain independent or localized breaks down for spinel minerals and other aluminate structures where substantial coupling with lattice modes is observed (cf. Jeanloz 1980).

IR techniques have been successfully employed in distinguishing six-fold from fourfold co-ordinated Al in synthetic aluminosilicate gels (Farmer et al 1979) and in aluminous serpentines (Serna et al 1977, 1979). But the technique has had only limited application to aluminosilicate glasses (Taylor and Green 1987). The suitability of IR spectroscopy in distinguishing $\mathrm{Al}$ co-ordination environments is discussed in $\S 4$ with reference to the systems $\mathrm{Na}_{2} \mathrm{O}-\mathrm{SiO}_{2}, \mathrm{Na}_{2} \mathrm{O}-\mathrm{Al}_{2} \mathrm{O}_{3}-\mathrm{SiO}_{2}$ and data on the IR spectra of aluminosilicate minerals.

\section{Experimental}

To illustrate the usefulness of IR spectroscopy in aluminosilicate glass structural studies, a series of glasses in the systems $\mathrm{Na}_{2} \mathrm{O}-\mathrm{SiO}_{2}$ (NS) and $\mathrm{Na}_{2} \mathrm{O}-\mathrm{Al}_{2} \mathrm{O}_{3}-\mathrm{SiO}_{2}$ 
(NAS) were synthesized at $1 \mathrm{~atm}$. The glasses were prepared from analytical grade $\mathrm{Na}_{2} \mathrm{CO}_{3}, \mathrm{SiO}_{2}$ and $\mathrm{Al}_{2} \mathrm{O}_{3}$. Appropriate proportions were ground in an agate mortar until sufficiently homogenized, they were then sintered at $800^{\circ} \mathrm{C}$ to drive off $\mathrm{CO}_{2}$, reground, then melted in a $\mathrm{Pt}$ crucible at $1100-1200^{\circ} \mathrm{C}$ and quenched in air. Glasses of $\mathrm{NaCaAlSi}_{2} \mathrm{O}_{7}$ (sodamelilite or $\mathrm{Sm}$ ), $\mathrm{NaAlSi}_{2} \mathrm{O}_{6}$ (jadeite or $\mathrm{Jd}$ ), $\mathrm{Ca}_{2} \mathrm{MgSi}_{2} \mathrm{O}_{7}$ (akermanite or $\mathrm{Ak}$ ) and $\mathrm{CaAl}_{2} \mathrm{Si}_{2} \mathrm{O}_{7}$ (gehlenite or $\mathrm{Geh}$ ) composition were similarly prepared except that $\mathrm{Ak}$ and Geh were quenched from $\sim 1600^{\circ} \mathrm{C}$. Crystalline jadeite and sodamelilite were prepared in piston cylinder apparatus at $25 \mathrm{~kb}$ and $30 \mathrm{~kb}$ respectively from the sintered oxides.

IR spectra were recorded over the range $4000-400 \mathrm{~cm}^{-1}$, using a Digilab FTS-20E Fourier Transform IR spectrometer and employing the conventional $\mathrm{KBr}$ disc method. Approximately $2 \mathrm{mg}$ (1 mg for crystalline compounds) of sample was ground together with $200 \mathrm{mg}$ of IR-grade $\mathrm{KBr}$ in an agate mortar for 10 minutes. After drying the powder at $110^{\circ} \mathrm{C}$, pellets were pressed between $1 \mathrm{~cm}$ diameter polished stainless steel dies; any cloudy discs were remade. Discs were then dried under $\mathrm{P}_{2} \mathrm{O}_{5}$ desiccant overnight to remove traces of absorbed water.

For the $\mathrm{Na}_{2} \mathrm{O}-\mathrm{SiO}_{2}$ glasses, the $\mathrm{KBr}$ discs were prepared under a $\mathrm{N}_{2}$ atmosphere with storage under $\mathrm{NaOH}$ desiccant to minimize the effects of atmospheric $\mathrm{H}_{2} \mathrm{O}$ and $\mathrm{CO}_{2}$ absorption to which these glasses are particularly susceptible. Spectrum acquisition was performed by signal-averaging 200 scans referenced against a blank $\mathrm{KBr}$ disc. A resolution of $4 \mathrm{~cm}^{-1}$ was employed.

\section{Results and discussion}

\subsection{System $\mathrm{Na}_{2} \mathrm{O}-\mathrm{SiO}_{2}(\mathrm{NS})$}

FTIR spectra of the compositions $\mathrm{NS}_{5}$ (pentasilicate, $\mathrm{Na}_{2} \mathrm{Si}_{5} \mathrm{O}_{11}$ ), $\mathrm{NS}_{3}$ (trisilicate, $\mathrm{Na}_{2} \mathrm{Si}_{3} \mathrm{O}_{7}$ ) and $\mathrm{NS}_{2}$ (disilicate, $\mathrm{Na}_{2} \mathrm{Si}_{2} \mathrm{O}_{5}$ ) having $\mathrm{NBO} / \mathrm{Si}$ ratios of $0.4,0.667$ and 1.0 respectively are shown in figure 1 . The effects of network depolymerization as $\mathrm{Na}_{2} \mathrm{O} / \mathrm{SiO}_{2}$ increases are clearly illustrated in the high frequency $\left(1200-800 \mathrm{~cm}^{-1}\right)$ region. In $\mathrm{NS}_{5}$ only one band envelope, centred at $1046 \mathrm{~cm}^{-1}$, is resolved in this region. It arises largely from antisymmetric stretching of $\mathrm{Si}-\mathrm{O}-\mathrm{Si}$ bridging groups and may be designated $v_{\text {as }}[\mathrm{Si}-\mathrm{O}-\mathrm{Si}]$. With increasing amounts of NBO the shoulder seen near $1000 \mathrm{~cm}^{-1}$ grows into a visually resolvable band envelope centred at $982 \mathrm{~cm}^{-1}$ in $\mathrm{NS}_{3}$ and $941 \mathrm{~cm}^{-1}$ in $\mathrm{NS}_{2}$. This causes the width of the high frequency envelopes to increase and extend below $800 \mathrm{~cm}^{-1}$. The lower frequency band of the high frequency doublet may be assigned largely to antisymmetric stretching of $\mathrm{Si}-\mathrm{O}^{-}$ non-bridging bonds $\left(v_{\mathrm{as}}\left[\mathrm{Si}-\mathrm{O}^{-}\right]\right)$with some contribution arising from symmetric $\mathrm{Si}-\mathrm{O}^{-}$stretching (the strongly Raman active $v_{\mathrm{s}}\left[\mathrm{Si}-\mathrm{O}^{-}\right]$bands) in the unresolved lowest frequency portion of the envelope. In the intermediate frequency range, $800-650 \mathrm{~cm}^{-1}$, a medium strength envelope appears at 781,768 and $760 \mathrm{~cm}^{-1}$ in the compositions $\mathrm{NS}_{5}, \mathrm{NS}_{3}$ and $\mathrm{NS}_{2}$ respectively. Vibrations contributing to this band are thought to be quite delocalized and involve substantial motion of $\mathrm{Si}$ atoms situated in their oxygen co-ordination cage ( $\$ 2 \cdot 2)$; additional contributions come from $\mathrm{Si}-\mathrm{O}-\mathrm{Si}$ in-plane bridge bending motions. Shoulders appearing near $660 \mathrm{~cm}^{-1}$ in $\mathrm{NS}_{2}$ and other more depolymerized compositions accompany a decrease in intensity of the $\sim 750 \mathrm{~cm}^{-1}$ band. These probably arise from symmetric stretching of the $\mathrm{Si}-\mathrm{O}-\mathrm{Si}$ bridge bond in pyrosilicate $\left(\mathrm{Si}_{2} \mathrm{O}_{7}\right)$ and other $\mathrm{Q}_{1}$-species that are likely 


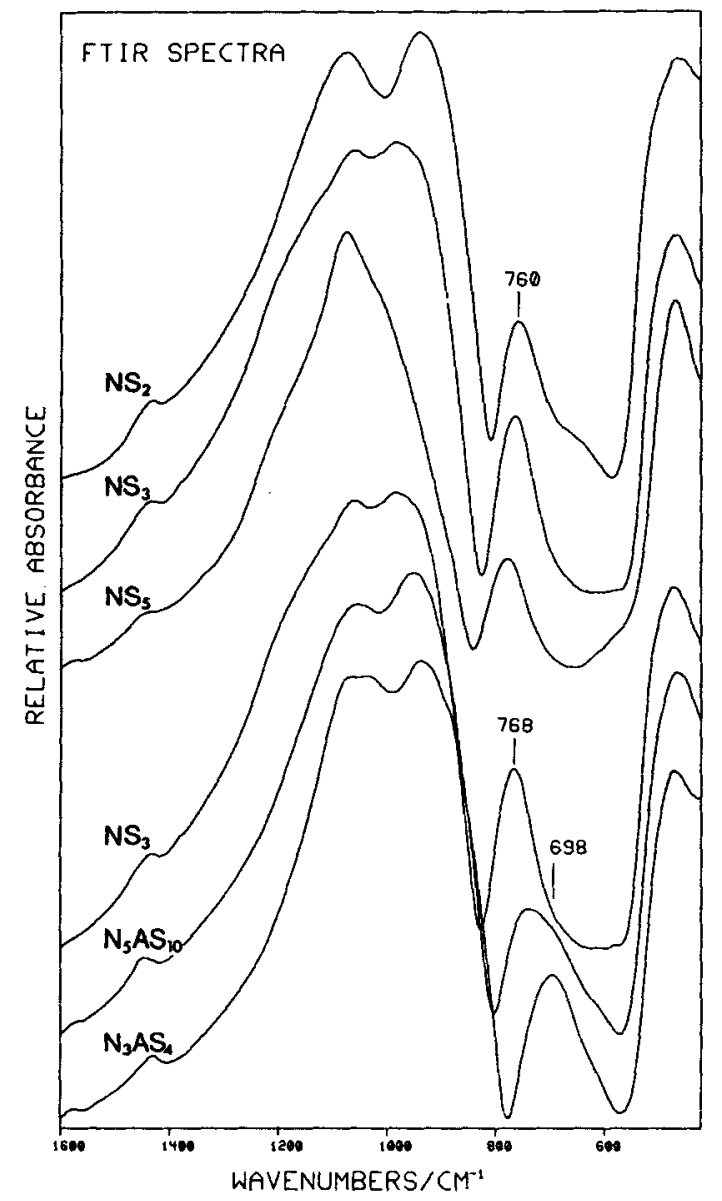

Figure 1. Fourier transform IR spectra $\left(1600-400 \mathrm{~cm}^{-1}\right)$ of the sodium silicate glasses $\mathrm{NS}_{2}$, $\mathrm{NS}_{3}, \mathrm{NS}_{5}$ and the sodium aluminosilicate glasses $\mathrm{N}_{5} \mathrm{AS}_{10}$ and $\mathrm{N}_{3} \mathrm{AS}_{4}\left(\mathrm{~N}=\mathrm{Na}_{2} \mathrm{O}, \mathrm{A}=\mathrm{Al}_{2} \mathrm{O}_{3}\right.$, $\mathrm{S}=\mathrm{SiO}_{2}$ ). Prominent high frequency bands in $\mathrm{N}_{3} \mathrm{AS}_{4}$ occur at 1072, 1034, 937, 870 (shoulder) and $698 \mathrm{~cm}^{-1}$.

to be present in these depolymerized glasses. A weak shoulder at $\sim 550 \mathrm{~cm}^{-1}$ in $\mathrm{NS}_{5}$ also occurs in pure silica glass and is assignable to in-plane $\mathrm{Si}-\mathrm{O}-\mathrm{Si}$ bridge bending vibrations. The low-frequency band envelope, $530-400 \mathrm{~cm}^{-1}$, is due to stretching plus bending-motions involving dominantly oxygen atom displacements. As predicted by Furukawa et al (1980), the low frequency bandwidth increases with increasing degree of depolymerization.

Bands present at $\sim 1430 \mathrm{~cm}^{-1}$ are due to small amounts of dissolved carbonate derived from absorbed atmospheric $\mathrm{CO}_{2}$. The amount present is not significant $(<1 \mathrm{wt} \%$ carbonate) in terms of its effect on the volatile-free glass structure.

\subsection{System $\mathrm{Na}_{2} \mathrm{O}-\mathrm{Al}_{2} \mathrm{O}_{3}-\mathrm{SiO}_{2}(\mathrm{NAS})$}

The effects of $\mathrm{Al}$ substitution have been investigated in the system $\mathrm{Na}_{2} \mathrm{O}-\mathrm{Al}_{2} \mathrm{O}_{3}-\mathrm{SiO}_{2}$ (NAS) by direct replacement of the charge-balanced component $\mathrm{NaAlO}_{2}$ for $\mathrm{SiO}_{2}$ in the trisilicate $\left(\mathrm{NS}_{3}\right)$ composition. Half a mole replacement gives $\mathrm{Na}_{2 \cdot 5}\left[\mathrm{Al}_{0.5} \mathrm{Si}_{2.5} \mathrm{O}_{7}\right]$ 
$\left(\mathrm{N}_{5} \mathrm{AS}_{10}\right)$ and one mole gives $\mathrm{Na}_{3}\left[\mathrm{AlSi}_{2} \mathrm{O}_{7}\right]\left(\mathrm{N}_{3} \mathrm{AS}_{4}\right)$. The latter composition is the sodic analogue of sodamelilite: $\mathrm{NaCa}\left[\mathrm{AlSi}_{2} \mathrm{O}_{7}\right]$. FTIR spectra of the series $\mathrm{NS}_{3}$, $\mathrm{N}_{5} \mathrm{AS}_{10}$ and $\mathrm{N}_{3} \mathrm{AS}_{4}$ show systematic shifts towards lower frequencies for both high frequency $v_{\text {as }}[\mathrm{NBO}]$ and $v_{\mathrm{as}}[\mathrm{BO}]$ bands and the mid-range envelope. These changes have been observed in studies of Al-substituted systems by Raman spectroscopy (Mysen et al 1981; Seifert et al 1982) and were associated with a coupling of Si-O and $\mathrm{Al}-\mathrm{O}$ stretching vibrations by these authors. McMillan et al (1982) have suggested a different interpretation whereby $\mathrm{Al}^{3+}$ acts only as a modifying cation in the manner of $\mathrm{Ca}^{2+}$ or $\mathrm{Na}^{+}$and vibrations maintain a high degree of $\mathrm{Si}-\mathrm{O}$ character. Since these two models can equally well describe the high frequency Raman spectra, there is at this stage, little to favour either model. The spectra of melilite crystals and glasses however reveal some important features in the interpretation of the structural versus spectroscopic role of $\mathrm{Al}$, relevant to both models (see later).

Compared'with $\mathrm{NS}_{3}$ glass, the $\mathrm{N}_{3} \mathrm{AS}_{4}$ composition has additional bands appearing in the FTIR spectrum at $1072 \mathrm{~cm}^{-1}$ and $880 \mathrm{~cm}^{-1}$ (shoulder). These may be compared with similar bands in the Raman spectra of gehlenite (Geh) and Ca-Tschermak's pyroxene (CaTs) composition glasses and crystals observed by Sharma et al (1983). Their origin has been attributed by the authors to increased localization of the high frequency stretching modes resulting from $\mathrm{Al} \leftrightarrow \mathrm{Si}$ substitution. On this basis, Sharma et al assigned the separate highest frequency bands to $v_{\text {as }}[\mathrm{Si}-\mathrm{O}-\mathrm{Si}]$ and $v_{\text {as }}[\mathrm{Si}-\mathrm{O}-\mathrm{Al}]$ vibrations. A similar interpretation may be made for the $1072 \mathrm{~cm}^{-1}$ and $1034 \mathrm{~cm}^{-1}$ bands in $\mathrm{N}_{3} \mathrm{AS}_{4}$ glass. The new shoulder at $\sim 880 \mathrm{~cm}^{-1}$ is best assigned to $\mathrm{Al}-\mathrm{O}$ stretching vibrations (McMillan et al 1982).

In the mid-frequency region there is a dramatic shift in the position of the mid-range band envelope from $768 \mathrm{~cm}^{-1}\left(\mathrm{NS}_{3}\right)$ through $745 \mathrm{~cm}^{-1}\left(\mathrm{~N}_{5} \mathrm{AS}_{10}\right)$ to $698 \mathrm{~cm}^{-1}$ $\left(\mathrm{N}_{3} \mathrm{AS}_{4}\right)$. An IR mid-range envelope centred near $700 \mathrm{~cm}^{-1}$ is characteristic of $\mathrm{NaAlO}_{2}$ or $\mathrm{Ca}_{0.5} \mathrm{AlO}_{2}$ substitution of the silicate network in numerous aluminosilicate glasses where $\mathrm{Al} /(\mathrm{Al}+\mathrm{Si})$ exceeds about $0 \cdot 25$. For example, jadeite, sodamelilite, albite, nepheline and gehlenite glasses all have mid-range band envelopes located near 700 $\mathrm{cm}^{-1}$. In Al-free systems the mid-range envelope is located at $\sim 800-750 \mathrm{~cm}^{-1}$ (McMillan 1984a). "Cage-like" motions of Al surrounded by a tetrahedral arrangement of oxygen give a calculated "reversal frequency" of $635 \mathrm{~cm}^{-1}$ in molecular dynamics simulations (Soules and Busby 1981). Because the mid-range absorption is strongly delocalized in behaviour, expected strong coupling between $\mathrm{Si}$ and $\mathrm{Al}$ vibrations is consistent with the observed frequency shift of the mid-range band to near $700 \mathrm{~cm}^{-1}$, i.e. intermediate between pure $\mathrm{Si}$ and $\mathrm{Al}$ "cage-like" vibrations. A mid-range envelope of medium to strong intensity situated near $700 \mathrm{~cm}^{-1}$ in aluminosilicate glasses is thus a good indication for the presence of network-substituted $\mathrm{AlO}_{4}$ polyhedra. This view is consistent with the study of Tarte (1967).

\subsection{Comparison of melilite and melilite-analogue glasses and crystals}

The IR spectrum of $\mathrm{N}_{3} \mathrm{AS}_{4}$ glass is in many respects similar to that of crystalline sodamelilite (figure 2) which is isostructural with the other melilite endmembers Ak and Geh (Louisnathan 1970b). Based on X-ray determinations, the melilite structure is best considered as a sheet-like arrangement of $\left[\mathrm{MT}_{2} \mathrm{O}_{7}\right]^{4-}$ groups (where $\mathrm{M}=\mathrm{Al}^{\mathrm{IV}}$, $\mathrm{Mg}$ or $\mathrm{Zn} ; \mathrm{T}=\mathrm{Al}^{\mathrm{lv}}$ or $\mathrm{Si}$ ) within which the nature of bonding is largely covalent; the adjacent sheets are held together by $\mathrm{Ca}^{2+}$ and $\mathrm{Na}^{+}$ions with interlayer bonding 


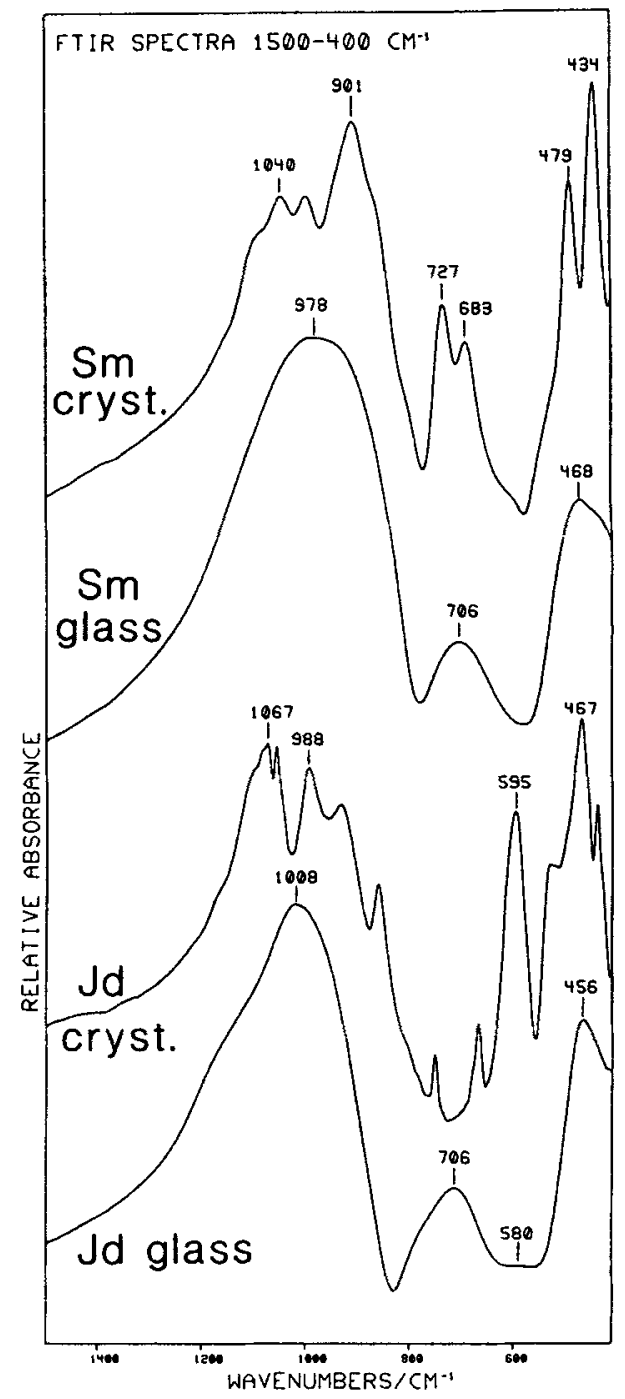

Figure 2. Fourier transform IR spectra $\left(1500-400 \mathrm{~cm}^{-1}\right)$ for crystalline and vitreous sodamelilite $(\mathrm{Sm})$ and jadeite $(\mathrm{Jd})$. The band at $595 \mathrm{~cm}^{-1}$ in crystalline jadeite is associated with $\mathrm{AlO}_{6}$ polyhedra.

being predominantly ionic (Louisnathan 1969). In sodamelilite $\mathrm{Al}$ and $\mathrm{Si}$ are ordered on tetrahedral sites and $\mathrm{Ca}$ and $\mathrm{Na}$ are disordered over the larger, distorted 8-coordination site. Since $\mathrm{N}_{3} \mathrm{AS}_{4}$ glass is spectroscopically similar to crystalline $\mathrm{Sm}$ (figure 2), it is likely that there is considerable $\mathrm{Al}$ and $\mathrm{Si}$ ordering on tetrahedral sites in this glass.

Raman and IR investigations of the melilite minerals have been carried out by Sharma et al (1983), Sharma and Yoder (1979) and Kimata (1979). Results of these studies together with additional FTIR spectroscopic data on melilite composition glasses (this work) have been summarized in tables 1 to 3 where tentative band assignments and correlations are given. 
Tables 1-3. IR and Raman spectral correlations for the melilite crystals and glasses.

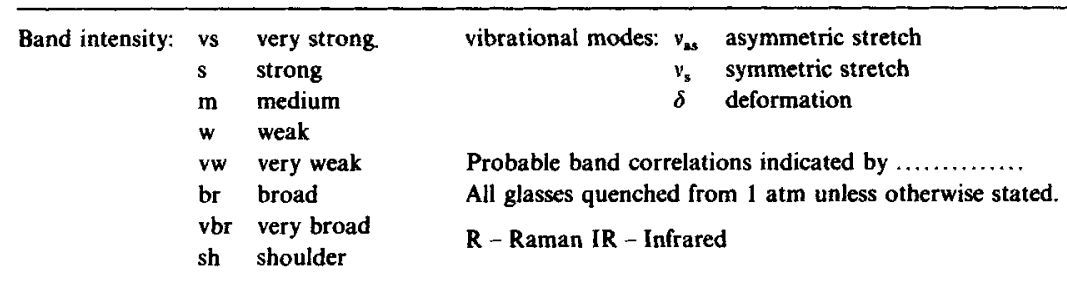

Table 1. Akermanite $\mathrm{Ca}_{2} \mathrm{MgSi}_{2} \mathrm{O}$,

\begin{tabular}{|c|c|c|c|c|c|c|}
\hline $\begin{array}{l}\text { IR \& } \mathrm{R} \\
\mathrm{Rb}_{2} \mathrm{~Pb}_{2} \mathrm{Si}_{2} \mathrm{O}_{7} \\
\text { linear bridge pyro- } \\
\text { silicate crystal } \\
\text { (Tarte et al } 1973 \text { ) }\end{array}$ & $\begin{array}{l}\text { IR } \\
\text { Hardystonite } \\
\text { (Zn-Ak) crystal } \\
\text { (Kimata 1980) }\end{array}$ & $\begin{array}{l}\text { IR } \\
\text { Ak crystal } \\
\text { (Kimata 1980) }\end{array}$ & $\begin{array}{l}\text { R } \\
\text { Ak crystal } \\
\text { (Sharma and } \\
\text { Yoder 1979) }\end{array}$ & $\begin{array}{l}\text { Tentative } \\
\text { assignments }\end{array}$ & $\begin{array}{l}\text { IR } \\
\text { Ak glass } \\
\text { (this } \\
\text { work) }\end{array}$ & $\begin{array}{l}\text { R } \\
\text { Ak glass } \\
\text { (Sharma and } \\
\text { Yoder 1979) }\end{array}$ \\
\hline \multirow{4}{*}{$1026 v_{\mathrm{as}}[\mathrm{Si}-\mathrm{O}-\mathrm{Si}]$} & & & $1067 v w$ & ...) & & \\
\hline & & $1044 \mathrm{sh}$ & & & & \\
\hline & 1010 s.............. & $1010 \mathrm{~s} . . . \ldots \ldots \ldots$ & $1023 \mathrm{vw}$ & $\ldots) v_{a s}[\mathrm{Si}-\mathrm{O}-\mathrm{Si}]$ & ) & \\
\hline & 970 s.............. & 973 s........... & $986 w$ & ․) & j964 vs & \\
\hline \multirow{4}{*}{$\begin{array}{l}913 v_{\mathrm{as}}\left[\mathrm{Si}-\mathrm{O}^{-}\right] \ldots \\
889 \mathrm{R} v_{\mathrm{s}}\left[\mathrm{Si}-\mathrm{O}^{-}\right] \ldots\end{array}$} & $920 \mathrm{vs} \ldots \ldots \ldots$ & 935 vs & & $\ldots) v_{a s}$ and & ) br & $914 \mathrm{~s}$ \\
\hline & 885 sh........... & $905 \mathrm{sh} . . . . . . . .$. & $904 \mathrm{~s}$ & $\ldots) v_{s}\left[\mathrm{Si}-\mathrm{O}^{-}\right]$ & & \\
\hline & $838 \mathrm{~s} \ldots \ldots \ldots \ldots$ & $.851 \mathrm{~s}$ & & $\ldots)$ & 847 sh.... & $858 \mathrm{sh}$ \\
\hline & $682 w \ldots \ldots \ldots \ldots$ & $685 w$ & & $v\left[\mathrm{SiO}_{4}\right] ?$ & ..)704 w sh & \\
\hline \multirow[t]{3}{*}{$668 \mathrm{R} v_{\mathrm{s}}[\mathrm{Si}-\mathrm{O}-\mathrm{Si}]$} & & & $661 \mathrm{~s}$ & $v_{s}[\mathrm{Si}-\mathrm{O}-\mathrm{Si}]$. & $\ldots ? \ldots \ldots \ldots$ & $683 \mathrm{~m}$ \\
\hline & $618 \mathrm{~s}, \ldots \ldots \ldots$ & $\begin{array}{r}(642 \mathrm{~m} \\
.(623 \mathrm{sh}\end{array}$ & & $\begin{array}{l}\ldots(\mathrm{Si}-\mathrm{O}-\mathrm{Si}] \\
\ldots)\end{array}$ & & \\
\hline & & $589 \mathrm{~m} \ldots \ldots \ldots$ & $598 w$ & $\ldots v\left[\mathrm{MgO}_{4}\right]$ &. $.579 \mathrm{sh}$ & \\
\hline \multirow[t]{2}{*}{$562 \delta\left[\mathrm{Si}-\mathrm{O}^{-}\right]$} & 549 sh. ... & $\begin{array}{l}(559 w \\
(520 \mathrm{sh}\end{array}$ & & 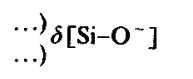 & $517 \mathrm{~s}$ & $533 w$ \\
\hline & $503 \mathrm{~s}$ & & & $v\left[\mathrm{ZnO}_{4}\right] ?$ & & \\
\hline $\begin{array}{l}4^{476)} \delta\left[\mathrm{Si}-\mathrm{O}^{-}\right] \\
452 \mathrm{R}) \\
407 \delta[\mathrm{Si}-\mathrm{O}-\mathrm{Si}]\end{array}$ & $455 \mathrm{~s} .$. & $478 \mathrm{~s} . \ldots \ldots \ldots$ & $\begin{array}{l}477 w \\
447 w\end{array}$ & $\ldots) \delta[0]$ & $482 \mathrm{sh}$ & \\
\hline
\end{tabular}

Bands due to $\mathrm{AlO}_{4}$ polyhedra are clearly identified for crystalline Geh by comparison with the gallium substituted analogue $\mathrm{Ca}_{2} \mathrm{Ga}_{2} \mathrm{SiO}_{7}$. They occur at 851 , 803 and $685 \mathrm{~cm}^{-1}$ and are also represented by bands at $850,810 \mathrm{~cm}^{-1}$ (weak shoulders) and $683 \mathrm{~cm}^{-1}$ in crystalline $\mathrm{Sm}$. The $850-800 \mathrm{~cm}^{-1}$ absorptions appear in the "characteristic frequency" range for condensed (i.e. interconnected) $\mathrm{AlO}_{4}$ polyhedra as defined by Tarte (1967) and are due to stretching vibrations of Al-O-Al linkages as discussed by McMillan et al (1982). The $\sim 680 \mathrm{~cm}^{-1}$ band is probably a stretching vibration largely involving motion of $\mathrm{Al}$ with its tetrahedral co-ordination cage. An analogous motion for $\mathrm{Si}$ is tentatively proposed for the bands near $700 \mathrm{~cm}^{-1}$ in crystalline Geh, Sm and Ak.

Despite the structural interpretations of Louisnathan $(1969,1970 \mathrm{a}, \mathrm{b})$ all the 
Table 2. Sodamelilite $\mathrm{NaCaAlSi}_{2} \mathrm{O}_{7}$.

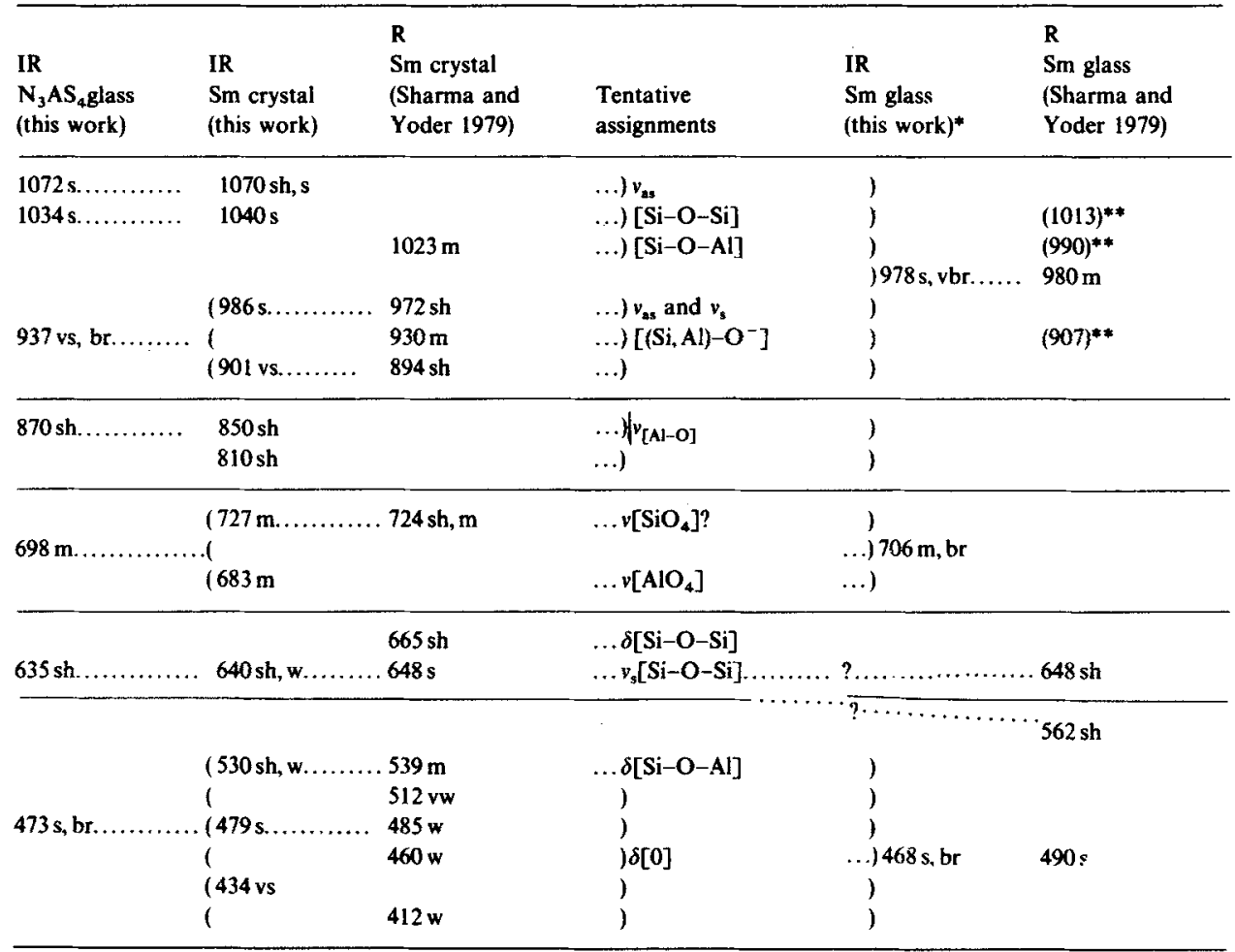

*Run T-1159 quenched from $30 \mathrm{kbar}$.

**Deconvolutions of $980 \mathrm{~cm}^{-1}$ band suggested by Mysen and Virgo (1980).

crystalline melilites exhibit spectral features, associated with the silicon-oxygen stretch bands, that strongly resemble those of pyrosilicate minerals and compounds (i.e. those containing $\left[\mathrm{Si}_{2} \mathrm{O}_{7}\right]^{6-}$ groups). The $\left[\mathrm{Si}_{2} \mathrm{O}_{7}\right]$ dimer must therefore be considered as the basic vibrating unit of the melilite minerals rather than the aluminosilicate sheet of Louisnathan. This implies strong localization of $\mathrm{Si}-\mathrm{O}$ and $\mathrm{M}-\mathrm{O}(\mathrm{M}=\mathrm{Al}, \mathrm{Mg}$ or $\mathrm{Zn}$ ) vibrations (i.e. negligible coupling) despite the fact that together they make up the integral $\left[\mathrm{MSi}_{2} \mathrm{O}_{7}\right]^{3-}$ structural unit of the melilite endmembers. Such an interpretation is similar to the model proposed by McMillan $(1984 \mathrm{a}, \mathrm{b})$ that argues against significant $\mathrm{Si}$, Al coupling of vibrational modes in aluminosilicate glasses.

As noted by Sharma and Yoder (1979), the IR and Raman spectra of Sm glass do not resemble the spectrum of the crystalline solid. However, the spectrum of $\mathrm{N}_{3} \mathrm{AS}_{4}$ glass, particularly in the high-frequency region, shows distinct similarity with that of crystalline Sm (figure 1 and 2). The absence in the glass of an intense IR band or band component near $900 \mathrm{~cm}^{-1}$, corresponding to the strong $v$ [NBO] band at this frequency in the crystal, indicates that the vibrating unit in $\mathrm{Sm}$ glass cannot be regarded as an $\left[\mathrm{Si}_{2} \mathrm{O}_{7}\right]$ group but rather must represent a much more polymerized aluminosilicate network structure with little $\mathrm{Al}, \mathrm{Si}$ ordering on tetrahedral sites. This conclusion is supported by Sharma and Yoder (1979) and Mysen and Virgo (1980); both studies suggest a structure dominated by network aluminosilicate unis of the 
Table A3. Gehlenite $\mathrm{Ca}_{2} \mathrm{Al}_{2} \mathrm{SiO}_{7}$

\begin{tabular}{|c|c|c|c|c|c|}
\hline $\begin{array}{l}\text { IR } \\
\text { Gallium subst. } \\
\text { Geh crystal } \\
\text { (Kimata 1980) }\end{array}$ & $\begin{array}{l}\text { IR } \\
\text { Geh crystal } \\
\text { (Kimata 1980) }\end{array}$ & $\begin{array}{l}\text { R } \\
\text { Geh crystal } \\
\text { (Sharma et al } \\
\text { 1983) }\end{array}$ & $\begin{array}{l}\text { Tentative } \\
\text { assignments }\end{array}$ & $\begin{array}{l}\text { IR } \\
\text { Geh glass } \\
\text { (this work) }\end{array}$ & $\begin{array}{l}\text { R } \\
\text { Geh glass } \\
\text { (Sharma et al } \\
\text { 1983) }\end{array}$ \\
\hline $1005 \mathrm{~s} . \ldots \ldots \ldots \ldots$ & $1022 \mathrm{~s} \ldots \ldots \ldots$ & $\begin{array}{l}1005 \mathrm{vw} \\
998 \mathrm{w}\end{array}$ & $\begin{array}{l}\ldots) v_{\text {as }} \\
\text { [Si-O-Si] } \\
\text { ] }[\mathrm{Si}-\mathrm{O}-\mathrm{Al}]\end{array}$ & $\ldots 984 \mathrm{~s}$ & $\ldots 1004$ w, sh \\
\hline \multirow[t]{2}{*}{$\begin{array}{l}945 \text { vs........... } \\
895 \mathrm{~s} \ldots \ldots \ldots \ldots \ldots \\
870 \mathrm{~s} \ldots \ldots \ldots \ldots \ldots\end{array}$} & $\begin{array}{l}970 \mathrm{~s} \ldots \ldots \ldots \ldots \ldots \\
917 \mathrm{~s} \ldots \ldots \ldots \ldots . \\
887 \mathrm{~s}\end{array}$ & $\begin{array}{l}977 \mathrm{~m} \\
.914 \mathrm{~m}\end{array}$ & $\begin{array}{l}\ldots) v_{\mathrm{x}} \& v_{\text {as }} \\
\ldots)\left[\mathrm{Si}, \mathrm{Al}-\mathrm{O}^{-}\right] \ldots \\
\ldots)\left[\mathrm{Si}, \mathrm{Ga}-\mathrm{O}^{-}\right]\end{array}$ & $\ldots 918 \mathrm{~s} \ldots \ldots$ & $\ldots 896 \mathrm{~s}$ \\
\hline & $\begin{array}{l}851 \text { s } \ldots \ldots \ldots \ldots . . \\
803 \text { vs } \ldots \ldots \ldots \ldots\end{array}$ & $\begin{array}{l}841 \mathrm{w}, \mathrm{sh} \\
.796 \mathrm{~m}\end{array}$ & $\ldots) v[\mathrm{Al}-\mathrm{O}]$ & $\begin{array}{l}\ldots 860 \mathrm{~s} \\
\ldots 818 \mathrm{sh}\end{array}$ & \\
\hline $718 \mathrm{~s} \ldots \ldots \ldots \ldots$ & $\begin{array}{l}717 \mathrm{~m} \\
685 \mathrm{~m}\end{array}$ & & $\begin{array}{l}\ldots v\left[\mathrm{SiO}_{4}\right] ? \\
\ldots v\left[\mathrm{AlO}_{4}\right]\end{array}$ & $\ldots)^{\prime} 690 \mathrm{~m}, \mathrm{sh}$ & \\
\hline $653 \mathrm{~s} \ldots \ldots \ldots \ldots$ & $648 \mathrm{~s} \ldots \ldots \ldots$ & $\begin{array}{l}.655 \mathrm{~m}, \mathrm{sh} \\
626 \mathrm{vs}\end{array}$ & $\begin{array}{l}\ldots \delta[\mathrm{Si}-\mathrm{O}-\mathrm{Si}] \\
\ldots v_{\mathrm{s}}[\mathrm{Si}-\mathrm{O}-\mathrm{Si}]\end{array}$ & & $\ldots 662 \mathrm{sh}$ \\
\hline $\begin{array}{l}583 \mathrm{~m} \\
550 \mathrm{~m} \\
525 \mathrm{~m}\end{array}$ & & & $\begin{array}{l}\ldots) v[\mathrm{Ga}-\mathrm{O}] \\
\ldots) \& \\
\ldots) v\left(\mathrm{GaO}_{4}\right]\end{array}$ & $\cdot ? \cdots$ & $552 \mathrm{~s}$ \\
\hline $503 \mathrm{~m} \ldots \ldots \ldots \ldots$ & $531 \mathrm{~m} \ldots \ldots \ldots \ldots$ & $.528 w$ & $\ldots \delta[\mathrm{Si}-\mathbf{O}-\mathrm{Al}]$ & & \\
\hline $472 \mathrm{~m} . \ldots \ldots \ldots$ & $\begin{array}{r}477 \mathrm{~m} \ldots \ldots \ldots \ldots \\
414 \mathrm{~s} \ldots \ldots \ldots \ldots\end{array}$ & $\begin{array}{l}.459 w \\
.425 \mathrm{vw}\end{array}$ & $\ldots) \delta[\mathrm{O}]$ & $\ldots)^{1} 457 \mathrm{~m}$ & \\
\hline
\end{tabular}

type $\left[\mathrm{NaAlSi}_{2} \mathrm{O}_{7}\right]^{2-}$ having $\mathrm{NBO} / \mathrm{T}=0.667$. The $\mathrm{Sm}$ analogue glasses $\mathrm{NS}_{3}$ and $\mathrm{N}_{3} \mathrm{AS}_{4}$ both have bulk NBO/T ratios of 0.667 but differ from Sm glass in that their spectra indicate the presence of substantial NBO. This may arise from greater localization of $\mathrm{Al}-\mathrm{O}$ and $\mathrm{Si}-\mathrm{O}$ stretching vibrations consistent with greater degree of $\mathrm{Al}, \mathrm{Si}$ order in $\mathrm{N}_{3} \mathrm{AS}_{4}$ glass coupled with a much less uniform distribution of structural units (i.e. Q-species) than found in Sm glass.

For Ak glass, IR and Raman spectra are similar to the crystalline phase suggesting that $\left[\mathrm{Si}_{2} \mathrm{O}_{7}\right]$ pyrosilicate groups are the dominant vibrating unit and in the absence of $\mathrm{Al}$ the melt structure is relatively depolymerized.

The Raman spectra of Geh glass and crystals are, in contrast to Ak, significantly different. Sharma et al (1983) found the glass to consist of a 3-d aluminosilicate network together with a high proportion of $\left[\mathrm{SiO}_{4}\right]^{4-}$ monomeric units identified by a strong band near $900 \mathrm{~cm}^{-1}$. A bimodal " $\mathrm{Q}_{0}-\mathrm{Q}_{4}$ " dispersion of tetrahedral environments is thus indicated (de Jong et al 1981).

\subsection{Aluminium co-ordination}

Vibrational spectra show that major structural differences occur in isochemical aluminosilicates when a change in $\mathrm{Al}$ co-ordination takes place. This difference is illustrated in figure 2 for crystalline and vitreous jadeite. In crystalline jadeite, $\mathrm{Al}$ is present as $\mathrm{AlO}_{6}$ polyhedra while in the glassy state $\mathrm{Al}$ occurs in tetrahedral coordination; major changes in the IR spectrum occur in the high frequency region 
and at mid-frequencies where a prominent band near $600 \mathrm{~cm}^{-1}$ in the crystal is no longer apparent in the glass phase. Other examples that show similar structural changes are $\mathrm{LiAl}^{\mathrm{IV}} \mathrm{Si}_{2} \mathrm{O}_{6}$ glass and the crystalline spodumene polymorphs (Sharma and Simons 1981) and vitreous and crystalline $\mathrm{CaTs}\left(\mathrm{CaAl}_{2} \mathrm{SiO}_{6}\right)(\mathrm{Sharma}$ et al 1983).

In both the above studies by Sharma, the structural changes could be readily characterized by Raman spectroscopy, although direct identification of bands due to $\mathrm{AlO}_{4}$ and $\mathrm{AlO}_{6}$ polyhedra was not possible. As discussed in $\$ 2$, IR spectroscopy is expected to be more sensitive to the nature of Al-O polyhedra and Tarte (1967) has suggested frequency ranges for bands indicative of Al-O polyhedra:

$\begin{array}{lll} & \mathrm{AlO}_{4} & \mathrm{AlO}_{6} \\ \text { Isolated polyhedra: } & 800-650 & 530-400 \\ \text { Condensed polyhedra*: } & 900-700 & 680-500\end{array}$

The ranges quoted by Tarte are broadly consistent with the presence of tetrahedrallyco-ordinated $\mathrm{Al}$ in the aluminosilicate glasses investigated in this study although the delocalized nature of the mid-range envelope (i.e. coupling with Si vibrations) does not allow definite identification of $\mathrm{AlO}_{4}$ in aluminosilicate glasses. Vibrations of $\mathrm{AlO}_{6}$ groups are probably better approximated as independent (Rao and Elliot 1981) and this has been used by Farmer et al (1979) and Serna et al (1977) to distinguish octahedrally-co-ordinated Al (identified by strong absorptions at $500-600 \mathrm{~cm}^{-1}$, see $\$ 2.4$ ). It is therefore tempting to suggest that the strong band at $595 \mathrm{~cm}^{-1}$ in crystalline jadeite (figure 2) which is absent or weak in the glass spectrum, can be assigned to a dominant contribution from $\mathrm{AlO}_{6}$ vibrations. As might be expected from this prediction, no band exists near $700 \mathrm{~cm}^{-1}$ in crystalline jadeite to indicate the presence of $\mathrm{AlO}_{4}$ but such a band does exist in crystalline and vitreous $\mathrm{Sm}$ which both contain tetrahedral Al (table 4, figure 2).

Reference to tabulated IR spectra (Liese 1975; Gadsden 1975) for a variety of silicate minerals, including structurally-related Al-containing and Al-free varieties, strongly supports the hypothesis that strong bands in the $520-620 \mathrm{~cm}^{-1}$ range are indicative of octahedrally-bound Al. While there are a few notable exceptions to the rule (such as the feldspar and scapolite series which have medium to strong IR bands in this region presumably related to their four-membered ring structures) there is a good general agreement for a diverse range of mineral structures and compositions, as summarized in table 4 . The natural extension of this rule is to aluminosilicate glasses where direct identification of $\mathrm{AlO}_{6}$ polyhedra has not been possible with other vibrational spectroscopic techniques. Bands in the $520-620 \mathrm{~cm}^{-1}$ region may thus indicate the presence of $\mathrm{AlO}_{6}$ polyhedra. Interference by other IR bands in this region may occur due to the presence of $\mathrm{Si}-\mathrm{O}-\mathrm{Si}$ bridge bending vibrations (only expected in pure silica and silica-rich glasses), bands associated with three- or four-membered ring structures (as in the feldspars and scapolites) and absorptions arising from defect centres. The last mentioned case is somewhat controversial and the existence of defect centres in aluminosilicate glasses is now regarded as doubtful (McMillan 1984a).

In aluminosilicate glasses spectral evidence indicates that tetrahdrally co-ordinated $\mathrm{Al}$ is the dominant species. In $1 \mathrm{~atm} \mathrm{Jd}$ and $\mathrm{Ne}$ (nepheline) composition glasses a weak band exists at $\sim 580 \mathrm{~cm}^{-1}$ (figure 2) which may indicate the presence of a small amount of non-network, octahedrally-co-ordinated $\mathrm{Al}$, or alternatively four-membered ring structures may be present. Mysen et al (1980) found no changes in the silicate 
Table 4. Relationship between six-fold Al co-ordination and IR bands in the region $520-620 \mathrm{~cm}^{-1}$.

\begin{tabular}{|c|c|c|}
\hline Mineral & $\begin{array}{l}\text { Al co-ordination } \\
\text { number }\end{array}$ & $\begin{array}{l}v s \text { or } s \text { bands } \\
520-620 \mathrm{~cm}^{-1}\end{array}$ \\
\hline Jadeite & 6 & 595 \\
\hline$\alpha$-spodumene & 6 & 590 \\
\hline Acmite & no $\mathbf{A l}$ & absent $(505-502)^{*}$ \\
\hline Diopside & no $\mathbf{A l}$ & absent $(513-510)^{*}$ \\
\hline Hedenbergite & no $\mathbf{A l}$ & absent $(515-509)^{*}$ \\
\hline Kyanite & 6 & $598-597$ \\
\hline Sillimanite & 6,4 & $545-544$ \\
\hline Andalusite & 6,5 & $535-520$ \\
\hline Mullite & 6,4 & $560-550$ \\
\hline Topaz & 6 & 609 \\
\hline Staurolite & 6 & $595-586$ \\
\hline Almandine** & 6 & $570-569$ \\
\hline Pyrope** & 6 & $575-565$ \\
\hline Grossular & 6 & $540-538$ \\
\hline Spessartine & 6 & $565-562$ \\
\hline Uvarovite & no $\mathbf{A l}$ & absent \\
\hline Andradite & no $\mathbf{A l}$ & absent $(512-510)^{*}$ \\
\hline Gibbsite & 6 & $562-540$ \\
\hline Kaolinite & 6 & $545-535$ \\
\hline Halloysite & 6 & $545-550$ \\
\hline Montmorillonite & 6,4 & 520 \\
\hline Pyrophyllite & 6 & $542-535$ \\
\hline Talc & no $\mathbf{A l}$ & absent \\
\hline Muscovite & 6,4 & 540 \\
\hline Phlogopite & 4 & absent \\
\hline Gehlenite & 4 & absent \\
\hline Sodamelilite & 4 & absent \\
\hline Zoisite & 6 & 575 \\
\hline
\end{tabular}

Data sources: Liese (1975) and Gadsden (1975).

*closest strong bands in the $\sim 500-600 \mathrm{~cm}^{-1}$ region.

**Omori (1971) calculates the $\mathrm{AlO}_{6}$ stretching frequency to be $\sim 630 \mathrm{~cm}^{-1}$ for Alm-Pyr garnet in reasonable agreement with the observed strong band at $\sim 570 \mathrm{~cm}^{-1}$.

network of Jd glass from $1 \mathrm{~atm}$ to $38 \mathrm{kbar}$ and thus find no evidence to suggest that an Al co-ordination change takes place with pressure as originally proposed by Kushiro (1976). These Raman results, however, do not preclude the presence of a small, constant proportion of octahedrally-co-ordinated Al in Jd mclt over the pressure range investigated. In hydrous $J d$ and $S m$ glasses, enhancement of the $570 \mathrm{~cm}^{-1}$ IR band indicates that measurable $\mathrm{AlO}_{6}$ is produced by $\mathrm{H}_{2} \mathrm{O}$ dissolution (Taylor and Green 1987).

Current techniques for the detection of $\mathrm{Al}$ co-ordination environments, including solid-state nuclear magnetic resonance (NMR) (de Jong et al 1983), do not appear sensitive enough to distinguish small proportions of $\mathrm{Al}^{\mathrm{VI}}$ in the presence of $\mathrm{Al}^{\mathrm{IV}}$, although at very high pressures gross co-ordination changes are readily identified 
(Ohtani et al 1985): the question of $\mathrm{Al}^{\mathrm{VI}}$ existence in lower pressure, anhydrous glasses remains open to further investigation.

\section{Summary}

The structure of silicate and aluminosilicate glasses has been investigated by IR spectroscopy complemented by data from earlier Raman studies. The IR spectra of glasses are more complex than Raman spectra in the high-frequency region $\left(1200-800 \mathrm{~cm}^{-1}\right)$. The high-frequency IR absorption envelope is composed of a series of bands that arise from both symmetric and antisymmetric stretching of $\mathrm{Si}-\mathrm{O}$ bonds in non-bridging and bridging positions in the silicate framework. These are well illustrated by glasses in the system $\mathrm{Na}_{2} \mathrm{O}-\mathrm{SiO}_{2}$.

It is shown that glasses of melilite and melilite-analogue (system NAS) composition exhibit a variety of different structural types ranging from those with significant NBO (Ak) to aluminosilicate network structures exhibiting limited $(\mathrm{Sm})$ or substantial $\left(\mathrm{N}_{3} \mathrm{AS}_{4}\right) \mathrm{Al}$, Si ordering or which contain a high proportion of other discrete units (Geh). The correlations between spectra (see tables 1-3) allow interpretation of the IR spectra of melilite and related glasses in terms of the basic vibrational units present. In the crystalline melilites and by analogy, in the vitreous phase as well, these units may not always correspond directly with the basic structural units identified by X-ray methods. This is believed mainly due to the effects of increasing band localization which may be correlated with the degree of tetrahedral site ordering. This suggestion has important implications for the structural role of $\mathrm{Al}$ as determined by vibrational spectroscopy since glasses of gross structural similarity may exhibit different degrees of $\mathrm{Al}, \mathrm{Si}$ ordering and hence significantly different vibrational spectra. The results for melilite glasses and crystals suggest that in aluminosilicate glasses such as $\mathrm{Sm}$, the high-frequency bands are best described by the delocalized or $\mathrm{Si}, \mathrm{Al}$ coupled vibrational model of Mysen and co-workers while in glass structures exhibiting more $\mathrm{Al}, \mathrm{Si}$ order, such as $\mathrm{N}_{3} \mathrm{AS}_{4}$, the model of McMillan and co-workers may be more appropriate.

In the glasses studied, the mid-range envelope of moderate IR intensity can be shown to respond in a predictable fashion to $\mathrm{NaAlO}_{2}$ or $\mathrm{Ca}_{0.5} \mathrm{AlO}_{2}$ substitution of the silicate network. This absorption arises from strongly delocalized vibrational modes asociated mainly with the aluminosilicate framework cations $\mathrm{Si}$ and $\mathrm{Al}$.

In aluminosilicate minerals and glasses it is shown that IR spectroscopy can be useful in discriminating Al co-ordination environments following the proposal of Tarte (1967). Al in six-fold co-ordination is characterized by absorption bands at $620-520 \mathrm{~cm}^{-1}$ in aluminosilicate minerals and glasses.

Useful future applications of IR spectroscopy may be in the far IR region (500-50 $\mathrm{cm}^{-1}$ ) where metal-anion complexes, such as those with fluoride (Foley et al 1986) or hydroxide, have characteristic vibrations.

\section{Acknowledgements}

The author thanks Drs A Finney, $\mathbf{R}$ Nordin, $\mathbf{S}$ Foley and $\mathbf{N}$ Odling for helpful discussions. $\mathrm{N}$ Davies and $\mathrm{K}$ Harris provided invaluable technical assistance, and 
Mrs M Hall (UWA) kindly assisted by typing the manuscript. This research was supported financially by an Australian National Research Fellowship to WRT and by Australian Research Council funds to Prof D H Green. This paper is dedicated to the late Sir C V Raman, on the occasion of his birth centenary.

\section{References}

Angell C A, Cheesman P A and Ramaddon S 1982 Tetrahedrally co-ordinated ionic liquids - anomalous transport properties and geophysical significance. In Ionic liquids, molten salts and polyelectrolytes, (eds) K-H Bennemann, F Brouers \& D Guitmann (Conf. Proc.) (Berlin Springer-Verlag) pp. 131-135

Bates J B, Hendricks R W and Shaffer L B 1974 Neutron irradiation effects and structure of noncrystalline $\mathrm{SiO}_{2} ; J$. Chem. Phys. $614163-4176$

Bell R J and Dean P 1972 Localization of phonons in vitreous silica and related glasses. In Physics of non-crystalline solids (eds.) R W Douglas \& B Ellis, Proc. Third Int. Conf. (New York: Wiley-Interscience) pp. 443-452

Borgianni C and Granati P 1979 Monte Carlo calculations of ionic structure in silicate and alumino-silicate melts; AIME Metall. Trans. B10 21-25

Bottinga Y, Weill D F and Richet P 1981 Thermodynamic modelling of silicate melts; Adv. Phys. Geochem. $1207-245$

Brawer S 1975 Theory of the vibrational spectra of some network and molecular glasses; Phys. Rev. B11 3173-3194

Brawer S A and White W B 1974 Raman spectroscopic investigation of the structure of silicate glasses 1. The binary alkali silicates; J. Chem. Phys. 63 2421-2432

de Jong B H W S, Keefer K D, Brown G E and Taylor C M 1981 Polymerisation of silicate and aluminate tetrahedra in glasses, melts and aqueous solutions - III. Local silicon environments and internal nucleation in silicate glasses; Geochim. Cosmochim. Acta 45 1291-1308

de Jong B H W S, Schramm C M and Parziale V E 1983 Polymerisation of silicate and aluminate tetrahedra in glasses, melts and aqueous solutions - IV. Aluminium co-ordination in glasses and aqueous solutions and comments on the aluminium avoidance principle; Geochem. Cosmochim. Acta 47 1223-1236

Dupree E and Pettifer R F 1984 Determination of the Si-O-Si bond angle distribution in vitreous silica by magic angle spinning NMR; Nature (London) 308 523-525

Engelhardt G, Zeigan D, Jancke H and Hoebbel D 1975 Zur abhanigkeit der Struktur der Silicatanionen in Wassrigen Natriumsilicatlosungen vom Na: Si Verhaltnis; Z. Anorg. Allg. Chem. 418 17-28

Farmer V C, Fraser A R and Tait J M 1979 Characterisation of the chemical structures of natural and synthetic aluminosilicate gels and sols by infrared spectroscopy; Geochim. Cosmochim. Acta 43 1417-1420

Ferraro J R and Manghnani M H 1972 Infrared absorption spectra of sodium silicate glasses at high pressure; J. Appl. Phys. 43 4395-4599

Foley S F, Taylor W R and Green D H 1986 The effect of fluorine on phase relationships in the system $\mathrm{KAlSiO}_{4}-\mathrm{Mg}_{2} \mathrm{SiO}_{4}-\mathrm{SiO}_{2}$ at $28 \mathrm{kbar}$ and the solution mechanism of fluorine in silicate melts; Contrib. Mineral. Petrol. 93 46-55

Furukawa T, Fox K E and White W B 1981 Raman spectroscopic investigation of the structure of silicate glasses-III. Raman intensities and structural units in sodium silicate glasses; J. Chem. Phys. 75 3226-3237

Gadsden J A 1975 Infrared spectra of minerals and related inorganic compounds; (London: Butterworths) 277 pp.

Galeener F L and Geissberger A E 1983 Vibrational dynamics in ${ }^{30}$ Si-substituted vitreous $\mathrm{SiO}_{2}$; Phys. Rev. B27 6199-6203

Galeener F L and Mikkelsen J C 1981 Vibrational dynamics in ${ }^{18} \mathrm{O}$-substitued vitreous $\mathrm{SiO}_{2}$; Phys. Rev. B23 5527-5530

Garofalini S H 1982 Molecular dynamics simulation of the frequency spectrum of amorphous silica; $J$. Chem. Phys. 76 3189-3192

Greaves G N, Fontaine A, Lagarde P, Raoux D and Gurman S J 1981 Local structure of silicate glass; Nature (London) 293 611-616

Hass M 1970 Raman spectra of vitreous silica, germania and sodium silicate glasses; J. Phys. Chem. Solids 31 $415-422$ 
Jeanloz R 1980 Infrared spectra of olivine polymorphs: alpha, beta phase and spinel; Phys. Chem. Miner. 5 327-341

Kimata M 1980 Crystal chemistry of Ca-melilites on X-ray diffraction and infrared absorption properties; Neues Jahrb. Mineral. Abh. 139 43-58

Kusabiraki K and Shiraishi Y 1981 The infrared spectrum of vitreous fayalite; J. Non-Cryst. Solids 44 365-368

Kushiro I 1975 On the nature of silicate melt and its significance in magma genesis: regularities in the shift of the liquidus boundaries involving olivine, pyroxene and silica minerals; Am. J. Sci. 275 411-431

Kushiro I 1976 Changes in viscosity and structure of melt of $\mathrm{NaAlSi}_{2} \mathrm{O}_{6}$ composition at high pressures; $J$. Geophys. Res. 81 6347-6350

Kushiro I 1978 Viscosity and structural changes of albite $\left(\mathrm{NaAlSi}_{3} \mathrm{O}_{8}\right)$ melt at high pressures; Earth Planet. Sci. Lett. $4387-91$

Kushiro I 1980 Viscosity, density and structure of silicate melts at high pressures, and their petrological implications. In Physics of magmatic processes (ed.) R B Hargreaves (Princeton: Univ. Press) pp. 93-121

Kushiro I 1984 Structures and some physical properties of silicate melts of geological interest. In Materials science of the earth's interior (ed.) I. Sunagawa (Tokyo: Terra Scientific Publ. Co.) pp. 39-60

Laughlin R B and Joannopoulos J D 1977 Phonons in amorphous silica; Phys. Rev. B16 2942-2953

Liese H C 1975 Selected terrestrial minerals and their infrared absorption spectral data $\left(4000-300 \mathrm{~cm}^{-1}\right)$. In Infrared and Raman spectroscopy of lunar and terrestrial minerals. (ed.) C Karr (New York: Academic Press) pp. 197-229

Louisnathan S J 1969 Refinement of the crystal structure of hardystonite, $\mathrm{Ca}_{2} \mathrm{ZnSi}_{2} \mathrm{O}_{7} ; Z$. Krist. 130 427-437

Louisnathan S J 1970a Refinement of the crystal structure of a natural gehlenite, $\mathrm{Ca}_{2} \mathrm{Al}(\mathrm{Al}, \mathrm{Si})_{2} \mathrm{O}_{7}$; $\mathrm{Can}$. Mineral. $10822-837$

Louisnathan S J 1970b The crystal structure of synthetic soda melilite, CaNaAlSi ${ }_{2} \mathrm{O}_{7} ; Z$. Krist. 131 314-321

Matsui Y and Kawamura K 1984 Computer simulation of structures of silicate melts and glasses. In Materials science of the earth's interior (ed.) I Sunagawa (Tokyo: Terra Scientific Publ. Co.) pp. 3-23

McMillan P 1984a Structural studies of silicate glasses and melts applications and limitations of Raman spectroscopy; Am. Mineral. $69622-644$

McMillan P 1984b A Raman spectroscopic study of glasses in the system $\mathrm{CaO}-\mathrm{MgO}-\mathrm{SiO}_{2} ; \mathrm{Am}$. Mineral. $69645-659$

McMillan P and Piriou B 1983 Raman spectroscopic studies of silicate and related glass structure - a review; Bull. Miner. 106 57-75

McMillan P, Piriou B and Navrotsky A 1982 A Raman spectroscopic study of glasses along the joins silica-calcium aluminate, silica-sodium aluminate, and silica-potassium aluminate; Geochim. Cosmochim. Acta 46 2021-2037

McMillan P,JakobssonS, Holloway JR and SilverLA 1983 A noteon the Raman spectra of water-bearingalbite glasses; Geochim. Cosmochim. Acta 47 1937-1943

Mysen B O and Virgo D 1980 Solubility mechanisms of carbon dioxide in silicate melts: A Raman spectroscopic study; Am. Mineral. $65885-899$

Mysen B O, Virgo D and Kushiro I 1981 The structural role of aluminium in silicate melts - a Raman spectroscopic study at 1 atmosphere; Am. Mineral. 66 678-701

Mysen B O, Virgo D and Scarfe C M 1980 Relations between anionic structure and viscosity of silicate melts - a Raman spectroscopic study; Am. Mineral. 65 690-710

Mysen B O, Virgo D and Seifert F A 1982 The structure of silicate melts: Implications for chemical and physical properties of natural magma; Rev. Geophys. Space Phys. 20 353-383

Navrotsky A, Peraudeau G, McMillan P and Coutures J-P 1982 A thermochemical study of glasses and crystals along the joins silica-calcium aluminate and silica-sodium aluminate; Geochim. Cosmochim. Acta 46 2039-2047

Ohtani E, Taulelle F and Angell C A $1985 \mathrm{Al}^{3+}$ co-ordination changes in liquid aluminosilicates under pressure; Nature (London) 314 78-81

Omori K 1971 Analysis of the infrared absorption spectrum of almandine-pyrope garnet from Nijosan, Osaka Prefecture, Japan; Am. Mineral. 56 841-849

Randall J T, Rooksby H P and Cooper B S 1930 Structure of glasses: the evidence of X-ray diffraction; $J$. Soc. Glass Technol. 14 219-229

Rao K J and Elliott S R 1981 Characteristic vibrations of cations in glasses, J. Non-Cryst. Solids 46 371-378

Sanders D M, Person W B and Hench L L 1974 Quantitative analysis of glass structure with the use of infrared reflection spectra; Appl. Spectrosc. 28 247-255 
Seifert F, Mysen B O and Virgo D 1982 Three-dimensional network structure of quenched melts (glass) in the systems $\mathrm{SiO}_{2}-\mathrm{NaAlO}_{2}, \mathrm{SiO}_{2}-\mathrm{CaAl}_{2} \mathrm{O}_{4}$ and $\mathrm{SiO}_{2}-\mathrm{MgAl}_{2} \mathrm{O}_{4} ;$ Am. Mineral. 67 696-717

Serna C J, Velde B D and White J L 1977 Infrared evidence of order-disorder in amesites; Am. Mineral. 62 296-303

Serna C J, White J L and Velde B D 1979 The effect of aluminium on the infrared spectra of $7 \AA$ trioctahedral minerals; Min. Mag. 43 141-148

Sharma S K and Simons B 1981 Raman study of crystalline polymorphs and glasses of spodumene composition quenched from various pressures; Am. Mineral. 66 118-126

Sharma S K, Simons B and Yoder H S 1983 Raman study of anorthite, calcium Tschermak's pyroxene and gehlenite in crystalline and glassy states; Am. Mineral. 68 1113-1125

Sharma S K and Yoder H S 1979 Structural study of glasses of akermanite, diopside and sodium melilite compositions by Raman spectroscopy; Rep. Geophys. Lab., Carnegie Inst. Washington, Yearb. 78 526-532

Soutes T F and Busby R F 1981 Sodium diffusion in alkali silicate glass by molecular dynamics; $J$. Chem. Phys. 75 969--975

Stolper E 1982a Water in silicate glasses: an infrared spectroscopic study; Contrib. Mineral. Petrol. 81 1-17

Stolper E 1982b The speciation of water in silicate melts; Geochim. Cosmochim. Acta $462609-2620$

Tarte P 1965 The determination of cation co-ordination in glasses by infrared spectroscopy. In Physics of non-crystalline solids (ed.) J A Prinz (New York: John-Wiley) pp. 549-565

Tarte $P 1967$ Infrared spectra of inorganic aluminates and characteristic vibrational frequencies of $\mathrm{AlO}_{4}$ tetrahedra and $\mathrm{AlO}_{6}$ octahedra; Spectrochim. Acta A23 2127-2143

Tarte P, Pottier M J and Proces A M 1973 Vibrational studies of silicates and germanates - V. I.R. and Raman spectra of pyrosilicates and pyrogermanates with a linear bridge; Spectrochim. Acta A29 1017-1027

Taylor $\mathrm{M}$ and Brown G E 1979 Structure of mineral glasses - II. The $\mathrm{SiO}_{2}-\mathrm{NaAlSiO}_{4}$ join; Geochim. Cosmochim. Acta 43 1467-1473

Taylor W R and Green D H 1987 The petrogenetic role of methane: Effect on liquidus phase relations and the solubility mechanism of reduced $\mathrm{C}-\mathrm{H}$ volatiles. In Magmatic processes: Physicochemical principles. (ed.) B O Mysen (The Geochemical Society, Special Publication No. 1) 121-138

Velde B and Kushiro I 1978 Structure of sodium aluminosilicate melts quenched at high pressure; infrared and aluminium K-radiation data; Earth Planet. Sci. Lett. 40 137-140

Verweij $\mathrm{H}$ and Konijnendijk W L 1976 Structural units in $\mathrm{K}_{2} \mathrm{O}-\mathrm{PbO}-\mathrm{SiO}_{2}$ glasses by Raman spectroscopy; J. Am. Ceram. Soc. 59 517-521

Virgo D, Mysen B O and Kushiro I 1980 Anionic constitution of 1-atmosphere silicate melts: Implications for the structure of igneous melts; Science 208 1371-1373

Woodcock L V, Angell C A and Cheeseman P 1976 Molecular dynamics studies of the vitreous state: Simple ionic systems and silica; J. Chem. Phys. 65 1565-1577

Wright A C and Leadbetter A J 1976 Diffraction studies of glass structure; Phys. Chem. Glasses 17 122-144

Zachariasen W H 1932 The atomic arrangement in glass; J. Am. Chem. Soc. 54 3841-3851 